УДК 616.341-007.272-089.168.1-06:616-008.6

DOI 10.11603/2414-4533.2017.3.8054

СА. Д. БЕДЕНЮК, А. Є. БУРАК

ДВН3 “Тернопільський державний медичний університет імені І. Я. Горбачевського МОз України”

\title{
Вплив комплексної післяопераційної терапії на стан ендогенної інтоксикації у хворих на гостру злукову тонкокишкову непрохідність у стадії декомпенсації
}

\begin{abstract}
Мета дослідження: вивчити динаміку показників ендогенної інтоксикації у хворих на гостру злукову тонкокишкову непрохідність у стадії декомпенсації під впливом комплексної післяопераційної терапії.

Матеріали та методи. Обстежено 182 хворих на гостру злукову непрохідність тонкої кишки. 3 них 152 (83,5 \%) пацієнти були прооперовані та 30 (16,5%) пацієнтів проліковані консервативно (контрольна група). Пацієнтів 3 декомпенсованою непрохідністю тонкої кишки в післяопераційному періоді лікували традиційним і запропонованим нами способом, який включав лаваж, оксигенотерапію (Патент України на корисну модель № 81097) та ентеральне харчування через інтубаційний зонд. Лаваж кишки проводили 0,9 \% розчином $\mathrm{NaCl}$, ентеральне харчування розпочинали з появи перистальтики (2-3 доба післяопераційного періоду) за допомогою розчину “Пептамен”. Також обстежено додаткову групу здорових осіб. 3 метою виявлення ендотоксемії визначали рівень молекул середньої маси фракцій 254 та 280 нм при госпіталізації та в динаміці лікування у оперованих та пролікованих консервативно хворих.

Результати дослідження та їх обговорення. Гостра хірургічна патологія призводить до накопичення у сироватці крові МСМ фракцій 254 і 280 нм. В ході лікування показники до 5 доби знижуються, стають меншими, ніж при госпіталізації, проте у всіх основних групах продовжують перевищувати рівень контрольної групи та здорових осіб. Розроблений нами спосіб післяопераційного лікування хворих на гостру тонкокишкову непрохідність у стадії декомпенсації вже з 3 доби після операції супроводжується вірогідно більшим зниженням вмісту в сироватці крові фракцій МСМ порівняно 3 аналогічними хворими, яких лікували стандартним методом.
\end{abstract}

Ключові слова: гостра кишкова непрохідність; ендогенна інтоксикація; молекули середньої маси.

Постановка проблеми і аналіз останніх досліджень та публікацій. Гостра кишкова непрохідність (ГКН) є широко розповсюдженим захворюванням у світі і належить до важливих проблем екстреної абдомінальної хірургії [1]. Частота цього захворювання у структурі хірургічної патології досягає 9,4 \% [2]. За даними вітчизняних та зарубіжних авторів щорічна захворюваність ГКН коливається в межах 4-25 чоловік на 100 тис. населення. Хворіють як чоловіки, так і жінки в будь-якому віці, проте найчастіше віком 40-60 років [3].

У патогенезі гострої кишкової непрохідності лежать два основні фактори: прогресуючий ендотоксикоз і порушення метаболізму в тканинах. Вони тісно пов'язані між собою і взаємообтяжують один одного [4]. Вивчення загальних рис морфології і функції структурних елементів та проявів синдрому ендогенної інтоксикації, закономірностей його розвитку, порушень зв'язків між окремими структурно-функціональними системами і їх регуляторними механізмами внаслідок реакції організму на дію токсинів $є$ актуальною фундаментальною проблемою в медицині, зокрема хірургії [5]. До сьогодні ендотоксикоз і перитоніт залишаються основними причинами летальних результатів при ГКН [6]. Актуальною проблемою зали- шається удосконалення методів лікування таких хворих. Це пояснюється високою летальністю, тривалим лікуванням, великим відсотком ускладнень на фоні розвитку синдрому поліорганних порушень [7].

Мета роботи: вивчити динаміку показників ендогенної інтоксикації у хворих на гостру злукову тонкокишкову непрохідність у стадії декомпенсації під впливом комплексної післяопераційної терапії.

Матеріали і методи. В основу нашого дослідження покладено аналіз клінічного обстеження, консервативного та хірургічного лікування 182 хворих на гостру злукову тонкокишкову непрохідність. 3 них 152 (83,5 \%) пацієнти були прооперовані та 30 (16,5 \%) пацієнтів проліковані консервативно. Чоловіків було 83 (45,6 \%), жінок - 99 (54,4 \%). Вік обстежених коливався від 20 до 85 років. Середній вік становив $(53,6 \pm 0,6)$ року.

Обстежені хворі були розподілені на 4 групи - 3 основні та контрольну. В основну групу $1(\mathrm{n}=58)$ ввійшли пацієнти в стадії компенсації, яким було виконано роз'єднання злук та дренування черевної порожнини. В основну групу 2 (n=49) ввійшли пацієнти в стадії декомпенсації, яким після ліквідації причини кишкової непрохід- 
ності інтраопераційно виконували назогастроінтестинальну інтубацію (НГІІ). Пацієнтам цієї групи в післяопераційному періоді інтубаційний зонд використовували лише для декомпресії та пасивного відтоку кишкового вмісту. Основну групу $3(\mathrm{n}=45)$ склали пацієнти в стадії декомпенсації, яким після ліквідації причини кишкової непрохідності інтраопераційно виконували НГІІ. В післяопераційному періоді пацієнтам цієї групи інтубаційний зонд використовували для проведення лаважу, оксигенотерапії (Патент України на корисну модель № 81097) та ентерального харчування. Лаваж кишки проводили 0,9 \% розчином $\mathrm{NaCl}$, ентеральне харчування розпочинали з появою перистальтики (2-3 доба післяопераційного періоду) за допомогою розчину “Пептамен”. Контрольну групу $(\mathrm{n}=30)$ склали неоперовані хворі в стадії компенсації, в яких кишкову непрохідність усунули консервативно. В комплексі консервативної терапії пацієнтів цієї групи для декомпресії шлунка використовували назогастральний зонд. Додаткову контрольну групу з метою вивчення і порівняння лабораторних показників склали 15 здорових осіб (студенти), в яких на момент обстеження не виявлено патології.

У всіх хворих визначали необхідні загальноклінічні та біохімічні показники на етапі госпіталізації, через 1 добу лікування та в його подальшій динаміці залежно від ефективності проведеного лікування. 3 метою виявлення ендотоксемії в сироватці крові визначали рівень фракцій молекул середньої маси (МСM), визначених при дов- жині хвилі 254 і 280 нм $\left(\mathrm{MCM}_{254}\right.$ і МСM $_{280}$ відповідно) [8].

Отримані цифрові дані обробляли статистично. Вірогідність відмінностей між дослідними і контрольною групами оцінювали з використанням програми STATISTICA (“StatSoft, Inc.”, США) на основі непараметричного критерію Манна-Уітні.

Результати досліджень та їх обговорення. Аналізуючи вплив комплексного лікування на вміст у крові фракцій молекул середньої маси у хворих з ГЗКН (табл. 1), виявлено, що у контрольній групі при госпіталізації порівняно зі здоровими спостерігався підвищений рівень $\mathrm{MCM}_{254}$ у сироватці крові - на 49,1 \% (p<0,05). У процесі лікування через 1 добу після госпіталізації даний показник зростав і ставав вищим від рівня здорових на 63,3 \% (p<0,05). У подальшому до 5 доби він знижувався, проте статистично вірогідно перевищував рівень здорових: через 3 доби - на 52,2 \% $(\mathrm{p}<0,05)$, через 5 діб - на 28,4 \% $(\mathrm{p}<0,05)$. На 5 добу лікування рівень MCM $_{254}$ був меншим, ніж при госпіталізації і через 1 та 3 доби (на 13,8, 21,3 і 15,7 \% відповідно, $\mathrm{p}<0,05)$.

В основній групі 1 при госпіталізації вміст $\mathrm{MCM}_{254}$ в сироватці крові був підвищеним порівняно 3 групою здорових на 88,5 \% $(\mathrm{p}<0,05)$. Через 1 добу післяопераційного періоду спостерігалось зростання рівня досліджуваного показника порівняно з здоровими особами - на 99,1 \% $(\mathrm{p}<0,05)$. В динаміці подальшого лікування його рівень поступово знижувався до 5 доби, проте статистично

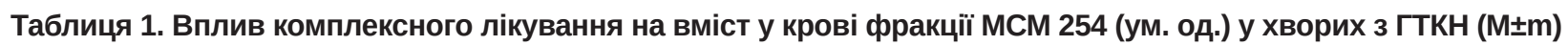

\begin{tabular}{|c|c|c|c|c|c|}
\hline \multirow{2}{*}{$\begin{array}{c}\text { Групи } \\
\text { хворих } \\
\end{array}$} & \multirow{2}{*}{$\begin{array}{c}\text { Здорові } \\
(n=15)\end{array}$} & \multirow{2}{*}{$\begin{array}{c}\text { При } \\
\text { госпіталізації }\end{array}$} & \multicolumn{3}{|c|}{ Термін спостереження } \\
\hline & & & 1 доба & 3 доба & 5 доба \\
\hline $\begin{array}{l}\text { Контрольна } \\
(n=30)\end{array}$ & \multirow{4}{*}{$\begin{array}{c}0,218 \pm \\
0,004\end{array}$} & $\begin{array}{l}0,325 \pm \\
0,007^{*}\end{array}$ & $\begin{array}{l}0,356 \pm \\
0,007^{*}\end{array}$ & $\begin{array}{c}0,332 \pm \\
0,015^{*}\end{array}$ & $\begin{array}{c}0,280 \pm \\
0,007^{*}{ }^{*}, 1,3\end{array}$ \\
\hline $\begin{array}{l}\text { Основна } 1 \\
(n=58)\end{array}$ & & $\begin{array}{l}0,411 \pm \\
0,006^{* \#}\end{array}$ & $\begin{array}{c}0,434 \pm \\
0,007^{* \# \text { г }}\end{array}$ & $\begin{array}{c}0,386 \pm \\
0,007^{* \#+1}\end{array}$ & $\begin{array}{c}0,332 \pm \\
0,007^{* \# r 1,3}\end{array}$ \\
\hline $\begin{array}{l}\text { Основна } 2 \\
(n=49)\end{array}$ & & $\begin{array}{l}0,599 \pm \\
0,013^{* \#}\end{array}$ & $\begin{array}{l}0,620 \pm \\
0,015^{* \#}\end{array}$ & $\begin{array}{c}0,577 \pm \\
0,010^{* \# 1} \\
\end{array}$ & $\begin{array}{c}0,520 \pm \\
0,005^{* \# r, 1,3}\end{array}$ \\
\hline $\begin{array}{l}\text { Основна } 3 \\
(n=45)\end{array}$ & & $\begin{array}{l}0,584 \pm \\
0,022^{* \#}\end{array}$ & $\begin{array}{l}0,592 \pm \\
0,011^{* \#} \\
\end{array}$ & $\begin{array}{c}0,445 \pm \\
0,010^{* \# r, 1} \\
\end{array}$ & $\begin{array}{c}0,354 \pm \\
0,003^{* \# \mathrm{r}, 1,3}\end{array}$ \\
\hline \multicolumn{2}{|c|}{$\mathrm{p}_{1-2}$} & $<0,05$ & $<0,05$ & $<0,05$ & $<0,05$ \\
\hline \multicolumn{2}{|c|}{$\mathrm{p}_{1-3}$} & $<0,05$ & $<0,05$ & $<0,05$ & $<0,05$ \\
\hline \multicolumn{2}{|c|}{$\mathrm{p}_{2-3}$} & $>0,05$ & $>0,05$ & $<0,05$ & $<0,05$ \\
\hline
\end{tabular}

Примітки. Тут і в інших таблицях:

* - відмінності стосовно здорових статистично вірогідні (p<0,05);

\# - відмінності стосовно контрольної групи статистично вірогідні $(\mathrm{p}<0,05)$;

$\mathrm{p}_{1-2}$ - вірогідність відмінностей між основними групами 1 і 2;

$\mathrm{p}_{1-3}$ - вірогідність відмінностей між основними групами 1 і 3;

$\mathrm{p}_{2-3}$ - вірогідність відмінностей між основними групами 2 і 3;

r, 1,3 - відмінності стосовно терміну відповідно при госпіталізації, на 1 і 3 доби лікування статистично вірогідні (p<0,05). 
вірогідно перевищував рівень здорових: через 3 доби - на 77,1 \% (р<0,05), а через 5 діб - на 52,3 \% $(\mathrm{p}<0,05)$. Через 5 діб лікування досліджуваний показник був меншим, ніж при госпіталізації і через 1 та 3 доби лікування ( на 19,2, 23,5 і 11,2 \% відповідно, $\mathrm{p}<0,05)$.

В основній групі 2 вміст досліджуваного показника при госпіталізації порівняно зі здоровими був підвищеним - у 2,74 раза $(\mathrm{p}<0,05)$. Через 1 добу після операції спостерігалось зростання його рівня відносно рівня групи здорових - у 2,84 раза (p<0,05). В динаміці подальшого лікування до 5 доби цей показник знижувався, проте статистично достовірно перевищував рівень здорових: через 3 доби - у 2,64 раза ( $<<0,05)$, а через 5 діб - у 2,38 раза $(\mathrm{p}<0,05)$. На 5 добу показник був істотно меншим, ніж при госпіталізації, через 1 та 3 доби лікування (на 13,2, 16,1 і 9,9 \% відповідно, p<0,05).

Серед пацієнтів основної групи 3 при госпіталізації вміст MCM $_{254}$ в сироватці крові теж був підвищеним порівняно з здоровими - у 2,67 раза $(\mathrm{p}<0,05)$. На 1 добу післяопераційного періоду спостерігалось зростання рівня цього показника - у 2,71 раза $(\mathrm{p}<0,05)$. В динаміці лікування його рівень знижувався до 5 доби, проте статистично вірогідно перевищував рівень здорових: на 3 добу - у 2,04 раза $(\mathrm{p}<0,05)$, на 5 добу - на 62,4 \% $(\mathrm{p}<0,05)$. На 5 добу післяопераційного періоду рівень MCM $_{254}$ був меншим, ніж при госпіталізації і на 1 та 3 добу (на 39,4, 40,2 і 20,4 \% відповідно, $\mathrm{p}<0,05$ ).

Порівняння величини досліджуваного показника між основними групами і контрольною показало, що і при госпіталізації і в ході лікування в основних групах вміст фракції MCM $_{254}$ у сироватці крові виявився статистично вірогідно більшим $(\mathrm{p}<0,05)$. Порівняння основних груп при госпіталізації та в динаміці лікування показало наступне.
При госпіталізації вміст у сироватці крові фракції $\mathrm{MCM}_{254}$ спостерігали найбільшим в основних групах 2 i 3, порівняно з основною групою 1 (на 45,7 i 42,1 \%, $\left.\mathrm{p}_{1-2}<0,05, \mathrm{p}_{1-3}<0,05\right)$. В цих групах показник був практично однаковим $\left(\mathrm{p}_{2-3}>0,05\right)$. В ході лікування через 1 добу вміст у сироватці крові фракції $\mathrm{MCM}_{254}$ так само виявили найбільшим в основних групах 2 і 3 порівняно з основною групою 1 (на 42,9 і 36,4 \% відповідно, $\mathrm{p}_{1-2}<0,05, \mathrm{p}_{1-}$ $\left.<0,05, \mathrm{p}_{2-3}>0,05\right)$. Через 3 доби лікування показник залишався вірогідно меншим в основній групі 1 (на 49,5 \% порівняно з основною групою 2, $\mathrm{p}_{1 \text { - }}$ ${ }_{2}<0,05$ та на $15,3 \%$ порівняно з основою групою 3 , $\left.\mathrm{p}_{1-3}<0,05\right)$. Привертає увагу той факт, що в даний термін в основній групі 3 вміст у сироватці крові фракції МСM $_{254}$ ставав статистично вірогідно меншим, ніж в основній групі 2 (на 29,7 \%, $\mathrm{p}_{2-3}<0,05$ ). Через 5 діб лікування величина досліджуваного показника в основних групах зменшувалася, проте він залишався істотно нижчим в основній групі 1 (на 56,6 \% порівняно з основною групою 2, p. $_{1-}$ ${ }_{2}<0,05$ та на 6,6 \% меншим порівняно $з$ основною групою $\left.3, \mathrm{p}_{1-3}<0,05\right)$. В основній групі 3 внаслідок запропонованого нами лікування показник був істотно меншим, ніж в основній групі 2, де виконували стандартну післяопераційну терапію (на 46,9\%, $\left.\mathrm{p}_{2-3}<0,05\right)$.

Як відображено в таблиці 2, у контрольній групі при госпіталізації порівняно зі здоровими відмічався підвищений рівень $\mathrm{MCM}_{280}$ У сироватці крові - на 19,3 \% ( $<0,05)$. В динаміці лікування до 5 доби цей показник поступово знижувався, проте статистично вірогідно перевищував рівень здорових: через 1 добу - на 13,9 \% ( $<0,05)$, через 3 доби на - 13,4 \% (p<0,05), через 5 діб - на 6,7 \% (p<0,05). Через 5 діб досліджуваний показник досягав мінімального рівня і був статистично вірогідно меншим, ніж при госпіталізації і через 1

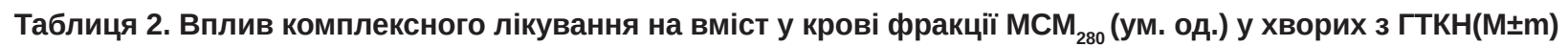

\begin{tabular}{|c|c|c|c|c|c|}
\hline \multirow{2}{*}{$\begin{array}{c}\text { Групи } \\
\text { хворих }\end{array}$} & \multirow{2}{*}{$\begin{array}{c}\text { Здорові } \\
(n=15)\end{array}$} & \multirow{2}{*}{$\begin{array}{c}\text { При } \\
\text { госпіталізації }\end{array}$} & \multicolumn{3}{|c|}{ Термін спостереження } \\
\hline & & & 1 доба & З доба & 5 доба \\
\hline $\begin{array}{l}\text { Контрольна } \\
(\mathrm{n}=30)\end{array}$ & \multirow{4}{*}{$\begin{array}{c}0,238 \pm \\
0,003\end{array}$} & $\begin{array}{c}0,284 \pm \\
0,006^{*}\end{array}$ & $\begin{array}{c}0,271 \pm \\
0,006^{*}\end{array}$ & $\begin{array}{c}0,270 \pm \\
0,006^{*}\end{array}$ & $\begin{array}{c}0,254 \pm \\
0,005^{*}, 1,3\end{array}$ \\
\hline $\begin{array}{l}\text { Основна } 1 \\
(n=58)\end{array}$ & & $\begin{array}{l}0,303 \pm \\
0,007^{* \#}\end{array}$ & $\begin{array}{l}0,342 \pm \\
0,006^{* \#{ }_{r}}\end{array}$ & $\begin{array}{c}0,320 \pm \\
0,007^{* \# 1} \\
\end{array}$ & $\begin{array}{c}0,290 \pm \\
0,007^{* \# 1,3}\end{array}$ \\
\hline $\begin{array}{l}\text { Основна } 2 \\
(n=49)\end{array}$ & & $\begin{array}{l}0,468 \pm \\
0,011^{* \#}\end{array}$ & $\begin{array}{l}0,476 \pm \\
0,009^{* \#}\end{array}$ & $\begin{array}{l}0,450 \pm \\
0,011^{* \#}\end{array}$ & $\begin{array}{c}0,438 \pm \\
0,005^{* \# r, 1}\end{array}$ \\
\hline $\begin{array}{l}\text { Основна } 3 \\
(\mathrm{n}=45)\end{array}$ & & $\begin{array}{l}0,453 \pm \\
0,010^{* \#}\end{array}$ & $\begin{array}{l}0,460 \pm \\
0,010^{* \#} \\
\end{array}$ & $\begin{array}{c}0,366 \pm \\
0,012^{*}{ }^{*}, 1\end{array}$ & $\begin{array}{c}0,322 \pm \\
0,004^{* \# \text { r, } 1,3}\end{array}$ \\
\hline \multicolumn{2}{|c|}{$\mathrm{P}_{1-2}$} & $<0,05$ & $<0,05$ & $<0,05$ & $<0,05$ \\
\hline \multicolumn{2}{|c|}{$\mathrm{p}_{1-3}$} & $<0,05$ & $<0,05$ & $<0,05$ & $<0,05$ \\
\hline \multicolumn{2}{|c|}{$\mathrm{P}_{2-3}$} & $>0,05$ & $>0,05$ & $<0,05$ & $<0,05$ \\
\hline
\end{tabular}


та 3 добу лікування (на 10,6, 6,3 і 5,9 \% відповідно, $\mathrm{p}<0,05)$.

В основній групі 1 при госпіталізації вміст $\mathrm{MCM}_{280}$ в сироватці крові був підвищеним порівняно зі здоровими на 27,3 \% (p<0,05). Через 1 добу після операції спостерігалось зростання рівня досліджуваного відносно рівня групи здорових - на 43,7 \% (p<0,05). У процесі лікування до 5 доби цей показник поступово знижувався, проте статистично достовірно перевищував рівень здорових: через 3 доби - на 34,4 \% (p<0,05), через 5 діб - на 23,1 \% (p<0,05). Через 5 діб досліджуваний показник досягав мінімального рівня і був статистично вірогідно меншим, ніж через 1 та 3 добу лікування (на 15,2 і 9,4 \% відповідно, р<0,05).

Серед пацієнтів основної групи 2 рівень досліджуваного показника при госпіталізації порівняно зі здоровими був підвищеним на - 96,6 \% (p<0,05). Через 1 добу післяопераційного періоду спостерігалось зростання рівня $\mathrm{MCM}_{280}$ у сироватці крові відносно рівня групи здорових - у 2 рази $(\mathrm{p}<0,05)$. В динаміці лікування до 5 доби цей показник знижувався, проте статистично вірогідно перевищував рівень здорових: через 3 доби - на $87,1 \%(\mathrm{p}<0,05)$, через 5 діб - на 84,0 \% $(\mathrm{p}<0,05)$. На 5 добу післяопераційного періоду показник був меншим, ніж при госпіталізації та через 1 добу лікування (на 6,4 і 8 \% відповідно, p<0,05), тоді як порівняно з 3 добою його динаміка знижувалась лише на $2,7 \%$ (p>0,05).

В основній групі 3 при госпіталізації вміст $\mathrm{MCM}_{280}$ У сироватці крові крові порівняно зі здоровими був підвищеним на 90,3 \% $(\mathrm{p}<0,05)$. Через 1 добу післяопераційного періоду спостерігалось зростання його рівня - на 93,3 \% ( $<<0,05)$. В динаміці подальшого лікування його рівень знижувався до 5 доби, проте статистично вірогідно перевищував рівень здорових: через 3 доби - на 53,8 \% $(\mathrm{p}<0,05)$, через 5 діб - на 35,3 \% ( $<<0,05)$. Привертає увагу той факт, що вже через 3 доби післяопераційного періоду вміст у крові фракції $\mathrm{MCM}_{280}$ ставав істотно меншим, ніж при госпіталізації та 1 добою лікування (на 19,2 і 20,4 \% відповідно, $\mathrm{p}<0,05)$. Досягаючи мінімального рівня через 5 діб показник виявився статистично вірогідно меншим, ніж при госпіталізації (на 28,9 \%, p<0,05) та порівняно з попередніми термінами спостереження (на 30 і 12 \% відповідно, $\mathrm{p}<0,05$ ).

Порівняння величини досліджуваного показника між основними групами і контрольною показало, що і при госпіталізації і в ході лікування в основних групах вміст фракції MCM $_{280}$ у сироватці крові виявився статистично вірогідно більшим $(p<0,05)$. Порівняння основних груп при госпіта- лізації та в динаміці лікування показало наступне. При госпіталізації вміст у сироватці крові фракції $\mathrm{MCM}_{280}$ спостерігали найбільшим в основних групах 2 і 3, порівняно з основною групою 1 (на 54,4 i $\left.49,5 \%, \mathrm{p}_{1-2}<0,05, \mathrm{p}_{1-3}<0,05\right)$. У ході лікування через 1 добу вміст у сироватці крові фракції $\mathrm{MCM}_{280}$ так само виявили найбільшим в основних групах 2 і 3 порівняно з основною групою 1 (на 39,2 i $34,5 \%$ відповідно, $\left.\mathrm{p}_{1-2}<0,05, \mathrm{p}_{1-3}<0,05, \mathrm{p}_{2-3}>0,05\right)$. У цих групах досліджуваний показник був практично однаковим $\left(\mathrm{p}_{2-3}>0,05\right)$. Через 3 доби лікування цей показник залишався вірогідно меншим в основній групі 1 (на 40,6 \% порівняно з основною групою 2, $\mathrm{p}_{1-2}<0,05$ та на 14,4 \% порівняно $з$ основою групою $\left.3, \mathrm{p}_{1-3}<0,05\right)$. Привертає увагу той факт, що в даний термін в основній групі 3 вміст у сироватці крові фракції MCM $_{280}$ ставав статистично вірогідно меншим, ніж в основній групі 2 (на 22,9 \%, $\left.\mathrm{p}_{2-3}<0,05\right)$. Через 5 діб лікування величина досліджуваного показника в основних групах зменшувалася, проте він залишався істотно нижчим в основній групі 1 (на $51 \%$ порівняно з основною групою 2 , $\mathrm{p}_{1-2}<0,05$ та на $11 \%$ меншим порівняно з основною групою $\left.3, \mathrm{p}_{1-3}<0,05\right)$. В основній групі 3 внаслідок запропонованого нами лікування показник був істотно меншим, ніж в основній групі 2, де в післяопераційному періоді виконували традиційне лікування (на $36 \%, \mathrm{p}_{2-3}<0,05$ ).

Таким чином, гостра хірургічна патологія призводить до накопичення у сироватці крові фракцій $\mathrm{MCM}_{254}$ і MCM $_{280}$ нм. В ході лікування показники до 5 доби знижуються, стають меншими, ніж при госпіталізації, проте у всіх основних групах продовжують перевищувати рівень контрольної групи та здорових осіб. Розроблений нами спосіб лікування хворих з гострою тонкокишковою непрохідністю (основна група 3) вже з 3 доби після операції супроводжується більшим зниженням вмісту в сироватці крові фракцій МСМ порівняно з аналогічними хворими, яких лікували традиційним методом (основна група 2). Через 3 i 5 діб післяопераційного періоду показник стає істотно меншим в основній групі 3, порівняно 3 основною групою 2.

Фракція $\mathrm{MCM}_{254}$ належить до інтегральних показників речовин низької і середньої молекулярної маси (від 500 Da до 5000 Da), до яких, крім пептидів, належать близько двохсот сполук нормального й аномального метаболізму. Вміст MCM $_{280}$ відображає переважно вміст ароматичних амінокислот і вказує на тяжкість поліорганної дисфункції [9]. Їх динаміка за умов досліджуваної патології виявилася практично однаковою, що свідчить про значний ступінь порушення метаболізму. 
Отже, запропонований нами комплексний підхід до післяопераційного лікування хворих з гострою тонкокишковою непрохідністю у стадії декомпенсації позитивно впливає на зменшення проявів ендотоксикозу і пов'язану з ним поліорганну дисфункцію. Очевидно, це пов'язано 3 пригніченням анаеробної кишкової мікрофлори, зменшенням надходження у кров мікробного токсину - ліпополісахариду, прискоренням пасажу кишкового вмісту. В цілому це зменшує токсичне навантаження на печінку, створює додаткові умови для посилення ії детоксикаційної функції.

Висновки. 1. Гостра хірургічна патологія призводить до накопичення у сироватці крові фракцій $\mathrm{MCM}_{254}$ та $\mathrm{MCM}_{280}$ В ході лікування показники до 5 доби стають меншими, ніж при госпіталізації, проте у всіх основних групах продовжують перевищувати рівень контрольної групи (лікованих консервативно) та здорових осіб.

\section{СПИСОК ЛІТЕРАТУРИ}

1. Eryuhin I. A. Ileus: a guide for physicians / I. A. Eryuhin, V. P. Petrov, M. D. Khanevich. - St., 1999. - 448 p.

2. Савельев В. С. Руководство по неотложной хирургии брюшной полости / В. С. Савельев. - М. : Триада-Х, 2004. -640 с.

3. Седов В. М. Острая кишечная непроходимость. Практическое пособие для студентов IV курса лечебного факультета и факультета спортивной медицины / В. М. Седов, Д. А. Смирнов, С. М. Пудяков. - СПб., 2002. - 25 с.

4. Feeding our immune system: impact on metabolism / I. Wolowczuk, C. Verwaerde, O. Viltart [et al.] // Clin. Dev. Immunol. - 2008. - P. 639-803. doi: 10.1155/2008/639803. Review.

5. Оценка основных причин летальных исходов у больных с абдоминальным сепсисом, обусловленным острыми хирургическими заболеваниями органов брюшной полости / Ю. М. Гаин, С. А. Алексеев, В. Г. Богдан [и др.] // Стратегия развития

\section{REFERENCES}

1. Eryuhin, I.A., Petrov, V.P. \& Khanevich, M.D. (1999). Ileus: a guide for physicians, St., 448.

2. Savelev, V.S. (2004). Rukovodstvo po neotlozhnoy hirurgii bryushnoy polosti [Guidlines for emergency abdominal surgery]. Moscow: Triada-X [in Russian].

3. Sedov, V.M., Smirnov, D.A. \& Pudyakov, S.M. (2002). Ostraya kishechnaya neprokhodimost. Prakticheskoe posobie dlya studentov IV kursa lechebnogo fakulteta i fakulteta sportivnoy meditsiny [Acute intestinal obstruction. Practical guidlines for students of the IV year of the Faculty of Medicine and the Faculty of Sports Medicine]. St. Petersburg [in Russian].

4. Wolowczuk, I., Verwaerde, C., Viltart, O., Delanoye, A., Delacre, M., Pot, B., \& Grangette, C. (2008). Feeding our immune system: impact on metabolism [Feeding our immune system: impact on metabolism]. Clin. Dev. Immunol. Review.

5. Gain, Yu.M., Alekseev, S.A., Bogdan, V.G., Kuzmin, Yu.V.,
2. Розроблений нами спосіб післяопераційного лікування хворих з гострою тонкокишковою непрохідністю у стадії декомпенсації, який включає HГII, лаваж тонкої кишки 0,9 \% розчином $\mathrm{NaCl}$, оксигенотерапію та ентеральне харчування з моменту появи перистальтики (2-3 доба післяопераційного періоду) за допомогою розчину “Пептамен”, вже з 3 доби після операції супроводжується вірогідно більшим зниженням вмісту в сироватці крові фракцій МСМ порівняно з аналогічними хворими, яких лікували стандартним методом.

Перспективи подальших досліджень. На основі отриманих результатів планується сформулювати концепцію визначення факторів виникнення, прогресування та взаємообтяження перебігу ГКН, сформулювати прогностичні критерії надання хірургічної допомоги залежно від перебігу та стадії патологічного процесу.

экстренной медицинской помощи: матер. науч.-практ. конф., посвящ. 25-летию БСМП / Под ред. Н. В. Завады. - Минск : РУП “Промпечать”. - 2003. - С. 199-200.

6. Small bowel emergency surgery: literature’s review / Carlo Vallicelli, Federico Coccolini, Fausto Catena [et al.] // World J. Emerg. Surg. - 2011. - Vol. 6. - P. 1.

7. Метаболическая терапия постперитонеальной интоксикации / А. П. Власов [и др.] // Клиническая медицина. - 2012. № 10. - С. 56-59.

8. Средние молекулы как вероятные регуляторы системы эритрона у спортсменов-лыжников / И. А. Волчегорский, Д. А. Дятлов, Е. И. Львовская [и др.] // Физиология человека. - 1996. - Т. 22, № 3. - С. 136-137.

9. Карякина Е. В. Молекулы средней массы как интегральный показатель метаболических нарушений : (обзор лит.) / Е. В. Карякина, С. В. Белова // Клиническая лабораторная диагностика. - 2004. -№ 3. - С. 3-7.
Dorokh, N.N. \& Sokolov, Yu.A. \& N.V. Zavadyy (Eds.). (2003). Otsenka osnovnykh prichin letalnykh iskhodov u bolnykh s abdominalnym sepsisom, obuslovlennym ostrymi khirurgicheskimi zabolevaniyami organov bryushnoy polosti [Assessment of the main causes of death in patients with abdominal sepsis due to acute surgical diseases of the abdominal organs]. Strategiya razvitiya ekstrennoy meditsinskoy pomoshchi: Mater. nauch.-prakt. konf., posvyasch. 25-letiyu BSMP - Strategy for the Development of Emergency Medical Care: Materials of the Scientific-Practical Conference Dedicated to the 25th Anniversary of the BSMP. Minsk: RUP "Prompechat" [in Russian].

6. Carlo Vallicelli, Federico Coccolini, Fausto Catena, Luca Ansaloni, Giulia Montori, Salomone Di Saverio, \& Antonio D. Pinna (2011). Small bowel emergency surgery: literature's review. World J. Emerg. Surg., 6, 1.

7. Vlasov, A.P. (2012). Metabolicheskaya terapiya postperito- 
nealnoy intoksikatsii [Metabolic therapy of postperitoneal intoxication]. Klinicheskaya meditsina - Clinical Medicine, 10, 56-59 [in Russian].

8. Volchegorskiy, I.A., Dyatlov, D.A. \& Lvovskaya, E.I.. (1996). Srednie molekuly kak veroyatnye regulyatory sistemy eritrona u sportsmenov-lyzhnikov [Medium molecules as probable regulators of the erythron system in athletes-skiers]. Fiziologiya cheloveka - Human Physiology, 22 (3), 136-137 [in Russian]. 9. Karyakina, E.V. \& Belova, S.V. (2004). Molekuly sredney massy kak integralnyy pokazatel metabolicheskih narusheniy: (obzor lit.) [Molecules of medium weight as an integral measure of metabolic disorders: (literature review)]. Klinicheskaya laboratornaya diagnostika - Clinical Laboratory Diagnostics, 3, 3-7 [in Russian].

\title{
INFLUENCE OF COMPLEX POSTOPERATIVE THERAPY ON THE CONDITION OF ENDOGENIC INTOXICATION IN PATIENTS WITH GASTRO-PULMONARY TOLERANCE INDEPENDENCE IN THE DECOMPENSATION STAGE
}

\begin{abstract}
The aim of the work: to learn the indicators of endogenous intoxication in dynamics in patients with acute articular small bowel obstruction at the stage of decompensation under the influence of complex postoperative therapy.

Materials and Methods. 182 patients with acute articular obstruction of the small intestine were examined. 152 (83.5 \%) patients among them were operated and 30 (16.5\%) patients were treated conservatively (control group). Patients with decompensated obstruction of the small intestine in the postoperative period were treated with the traditional and proposed by us method, which included lavage, oxygen therapy (Patent of Ukraine for Utility Model No. 81097) and enteral nutrition through an intubation probe. Lavage of the intestine was carried out with a $0.9 \%$ solution of $\mathrm{NaCl}$, enteral nutrition started with the appearance of peristalsis $\left(2^{\text {nd }}-3^{\text {rd }}\right.$ day of a postoperative period) with the solution of Peptaman. An additional control group, which consisted of healthy people, was also examined. In order to detect endotoxemia, the levels of the average mass fractions 254 and $280 \mathrm{~nm}$ were determined at hospitalization and in the dynamics of treatment in operated and treated conservatively patients.

Results and Discussion. Acute surgical pathology leads to the accumulation of fractions of MSM254 and MSM280 in serum. In the course of treatment, the rates up to 5 days reduce, become lower than during hospitalization, but in all major groups, they continue to exceed the level of the control group and healthy individuals. The method of postoperative treatment of patients with acute articular obstruction of the small intestine in the stage of decompensation was developed by us since 3 days after the operation, accompanied by a significantly lower decrease in the serum content of MSM fractions compared with similar patients treated with the standard method.
\end{abstract}

Key words: acute intestinal obstruction; endogenous intoxication; molecules of average mass.

\section{А. Д. БЕДЕНЮК, А. Е. БУРАК}

гВУз “Тернопольский государственный медицинский университет имени И. Я. Горбачевского МЗ Украины”

\section{В.ЛИЯНЕ КОМПЛЕКСНОЙ ПОС.ЛОПЕРАЦИОННОЙ ТЕРАПИИ НА СОСТОЯНИЕ ЭНДОГЕННОЙ ИНТОКСИКАЦИИ У БОЛЬНЫХ НА ОСТРУЮ СПАЕЧНУЮ ТОНКОКИШЕЧНУЮ НЕПРОХОДИМОСТЬ В СТАДИИ ДЕКОМПЕНСАЦИИ}

Цель работы: изучить динамику показателей эндогенной интоксикации у больных с острой спаечной тонкокишечной непроходимостью в стадии декомпенсации под влиянием комплексной послеоперационной терапии.

Материалы и методы. Обследовано 182 больных острой спаечной непроходимости тонкой кишки. Из них 152 (83,5 \%) пациенты были прооперированы и 30 (16,5%) пациентов пролечены консервативно (контрольная группа). Пациентов с декомпенсированной непроходимостью тонкой кишки в послеоперационном периоде лечили традиционным и предложенным нами способом, который включал лаваж, оксигенотерапию (Патент Украины на полезную модель № 81097) и энтеральное питание через интубационный зонд. Лаваж кишки проводили 0,9 \% раствором $\mathrm{NaCl}$, энтеральное питание начинали с появлением перистальтики (2-3 сутки послеоперационного периода) с помощью раствора “Пептамен”. Также обследовано дополнительную контрольную группу здоровых лиц. С целью выявления эндотоксемии определяли уровень молекул средней массы фракций 254 и 280 нм при госпитализации и в динамике лечения у оперированных и пролеченных консервативно больных.

Результаты исследования и их обсуждение. Острая хирургическая патология приводит к накоплению в сыворотке крови фракций МСM254 и МСM280. В ходе лечения показатели до 5 суток снижаются, становятся меньше, чем при госпитализации, однако во всех основных группах продолжают превышать уровень контрольной группы и здоровых лиц. Разработанный нами способ послеоперационного лечения больных с острой тонкокишечной непроходимостью в стадии декомпенсации уже с 3 суток после операции сопровождается достоверно большим снижением содержания в сыворотке крови фракций МСМ по сравнению с аналогичными больными, которых лечили стандартным методом.

Ключевые слова: острая кишечная непроходимость; эндогенная интоксикация; молекулы средней массы. 